\title{
Analisis Kinerja Karyawan di PT Intan Pariwara Klaten
}

${ }^{1}$ Julianti Nugraheni, ${ }^{2}$ Supawi Pawenang, ${ }^{3}$ Bambang Mursito Universitas Islam Batik, Kota Surakarta, Jawa Tengah, Indonesia Email:1 ${ }^{1}$ juliantinugraheni7@gmail.com,22pawipawenang@gmail.com, 3bambangmursito1959@gmail.com

(Diterima: Oktober 2021; Direvisi: Oktober 2021; Dipublikasikan: Januari 2022)

\begin{abstract}
ABSTRAK
Tujuan dari penelitian ini adalah untuk memastikan pengaruh variabelvariabel berikut; beban kerja, lingkungan, disiplin, dan kepuasan kerja pada kinerja karyawan PT. Intan Pariwara baik secara bersamaan maupun sebagian. Peneliti menggunakan metode deskriptif kuantitatif. Populasi penelitian ini adalah karyawan PT. Divisi keuangan Intan Pariwara yang terdiri dari 109 karyawan. Teknik pengambilan sampel menggunakan teknik sampling jenuh/sensus yang meliputi 109 responden. Peneliti menggunakan kuesioner untuk mengumpulkan data. Sedangkan metode analisis data menggunakan analisis statistik linier berganda uji regresi, uji $\mathrm{F}$, uji $\mathrm{T}$, dan koefisien determinasi. Hasil penelitian menunjukkan bahwa beban kerja, lingkungan, disiplin, dan kepuasan kerja semuanya memiliki pengaruh sebesar $42,5 \%$ terhadap kinerja karyawan. Sebagai perbandingan, 57,5\% dipengaruhi oleh variabel lain seperti motivasi kerja, pengaruh kompensasi kerja, dll.
\end{abstract}

\section{Kata Kunci: Kinerja, Beban Kerja, Lingkungan, Disiplin, Kepuasan}




\section{PENDAHULUAN}

Dalam era globalisasi serta kemajuan teknologi seperti saat ini, tiap perusahaan dituntut untuk mempunyai manajemen serta strategi yang berkualitas dalam meningkatkan suatu perusahaan. Manajemen perusahaan yang berkualitas tentu bisa menunjang daya saing suatu perusahaan. Daya saing suatu perusahaan dapat dikatakan cukup berhasil untuk dapat bersaing dengan perusahaan kompetitor. Sumber daya manusia ialah kedudukan utama dalam kemajuan perusahaan. Pegawai ataupun karyawan ialah faktor terutama dalam memastikan maju mundurnya sesuatu perusahaan. Maka dari itu dibutuhkan karyawan yang bermutu untuk perusahaan, sebab mutu karyawan ialah perihal yang amat berarti dalam cara perekrutan sumber daya manusia suatu perusahaan, dan wajib penuhi kualifikasi persyaratan dalam perusahaan, pastinya pula wajib sanggup melaksanakan tugas- tugas yang sudah ditetapkan oleh perusahaan. Untuk menggapai perihal itu, karyawan wajib mempunyai kinerja dalam melaksanakan pekerjaannya.

Kinerja ialah bagian yang sangat penting dan menarik hal ini dikarenakan kinerja sudah terbukti sangat penting manfaatnyaa, perusahaan membutuhkan pegawai untuk bertugas yang benar-benar cocok dengan keahlian yang dipunyai guna menggapai hasil kegiatan yang bagus, tanpa terdapatnya kinerja yang bagus dari seluruh pegawai, maka akan sulit untuk mencapai keberhasilan dalam mencapai tujuan. Kinerja ialah sesuatu guna dari dorongan serta keahlian untuk menuntaskan kewajiban ataupun pekerjaan (Sunarsi et al., 2020).

Beban kerja ialah kondisi yang nantinya pekerja diarahkan dalam kewajiban untuk dituntaskan di durasi khusus. Tiap kegiatan ataupun pekerjaan yang dicoba sesuatu pekerja tentu senantiasa memiliki sesuatu beban kerja. Dengan terdapatnya beban kerja, karyawan jadi bertanggung jawab dengan pekerjaan yang telah diserahkan pada karyawan itu. Beban kerja dicirikan selaku beberapa aktivitas, durasi, serta tenaga yang wajib dikeluarkan seorang bagus raga atau psikologis dengan membagikan kapasitas mereka untuk penuhi tuntutan tugas yang diberikan (Sugiharjo \& Aldata, 2018).

Lingkungan kerja bisa memberikan rasa nyaman serta aman alhasil membolehkan karyawan bisa bertugas dengan maksimal. Bila karyawan suka dengan area tempatnya bertugas, memiliki ikatan yang bagus dengan sesama anggota perusahaan, jadi komitmen dan loyalitas pegawai terhadap perusahaan akan lebih maksimal dan akan mendapatkan hasil kinerja yang baik. (Mufidah, 2017).

Disiplin kerja ialah tindakan, perilaku, serta aksi seorang yang sesuai dengan aturan organisasi sebagai usaha untuk tingkatkan pemahaman serta kemauan seorang supaya tidak melaksanakan kelalaian, penyimpangan ataupun kelengahan dalam melaksanakan pekerjaan. Pengertian tersebut cocok dengan kejadian yang terjalin di perusahaan (Ferawati, 2017). Disiplin kerja ialah aspek penting yang mempengaruhi kinerja pegawai. Di dalam sesuatu perusahaan, disiplin kerja amat 
dicermati supaya pimpinan perusahaan dapat memperhitungkan kinerja dari karyawan itu, apakah karyawan dalam bekerja akan menanamkan kedisiplinan kerja dalam dirinya.

Tidak hanya beban kerja, lingkungan kerja, serta kepuasan kerja, kepuasan kerja juga menjadi aspek berarti dalam penelitian ini, sebab bila kita mengetahui kepuasan kerja karyawan, kita memandang pula dari hasil kinerjanya. Karyawan yang memiliki kepuasan kepada pekerjaannyasudah tentu memiliki loyalitas terhadap perusahaan, serta karyawan itu akan melaksanakan pekerjaan yang diberikan kepadanya dengan rasa tanggung jawab (Zahara \& Hidayat 2017). Penelitian ini untuk menguji analisis kinerja karyawan di PT. Intan Pariwara Klaten.

\section{TINJAUAN PUSTAKA}

\section{Kinerja}

Sinambella et al (2011: 136), mengemukakan jika kinerja karyawan didefinisikan sebagai kemampuan karyawan dalam melaksanakan suatu kinerja yang tertentu. Menurut Kasmir (2016: 208- 210), menerangkan bahwasanya ada 6 indikator kinerja karyawan guna mengukur sejauh mana kinerja karyawan, yakni:
a. Diperlukan kuantitas
b. Diperlukan kualitas
c. Adanya waktu
d. Adanya kerjasama antarkaryawan
e. Adanya penekanan untuk biaya
f. Adanya Pengawasan

\section{Beban Kerja}

Menurut Hannani (2016: 4), menyatakan bahwa beban kerja yaitu keadaan yang dihasilkan antar jaringan dari persyaratan tugas - tugas, lingkungan kerja dimana ditempakan selaku rekan kerja, keterampilan, sikap, serta persepsi dari pekerja. Menurut Koesomowidjojo (2017: 33), penentuan indikator yang wajib di peroleh karyawan guna mengetahui besarnya beban kerja di perusahaan yakni:

a. Targetan yang wajib digapai

b. Keadaan dari pekerjaan

c. Pemakaian waktu

\section{Lingkungan}

Menurut Danang (2015:38), lingkungan kerja merupakan kondisi sekitar dimana di kawasan tersebut dapat berefek pada individu itu sendiri guna melaksanakan tugas-tugas yang telah diberikan kepadanya. Menurut Sedarmayanti (2011:15), indikator dari lingkungan kerja yakni:
a. Cahaya/sinar yang masuk di tempat kerja
b. Aliran udara ditempat kerja
c. Keramaian dikawasan kerja
d. Bau yang mengganggu/tidak sedap dikawasan kerja
e. Pengawasan/keamanan dikawasan kerja

\section{Disiplin}

Menurut Sinambela (2018: 335), disiplin kerja ialah perlengkapan yang dipakai atasan untuk berbicara dengan karyawan supaya mereka mau mengubah sikap mengikuti aturan main yang sudah di tetapkan. Bagi Mangkunegara \& Octorent( 2015: 323) disiplin kerja bisa diukur dengan indikator:

a. Ketepatan waktu dari karyawan yang berkunjung ke kantor. 
b. Ketepatan waktu dari karyawan saat pulang dari kantor.

c. Kepatuhan terhadap aturan kerja yang berlaku.

d. Pemakaian seragam kerja yang sudah ditetapkan.

e. Tanggungjawab dalam melakukan kewajiban.

f. Melakukan tugas - tugas kegiatan hingga berakhir tiap harinya.

5. Kepuasan Kerja

Sutrisno (2014: 75), menerangkan bahwasanya kepuasan ialah suatu situasi emosional yang menggairahkan atau kurang menyenangkan bagi karyawan untuk melihat pekerjaannya. Kepuasan kerja menggambarkan perasaan ataupun sikap seeorang kepada pekerjaannya.Rivai (2013: 479480) berpendapat bahwasanya ada indikator dari kepuasan kerja yakni:

a. Isi pekerjaan yang di handle

b. Supervisi dari perusahaan

c. Organisasi serta manajemen yang ada di perusahaan

d. Adanya peluang karyawan untuk makin maju

e. Teman kerja

f. Situasi/kondisi dari pekerjaan

\section{Hipotesis}

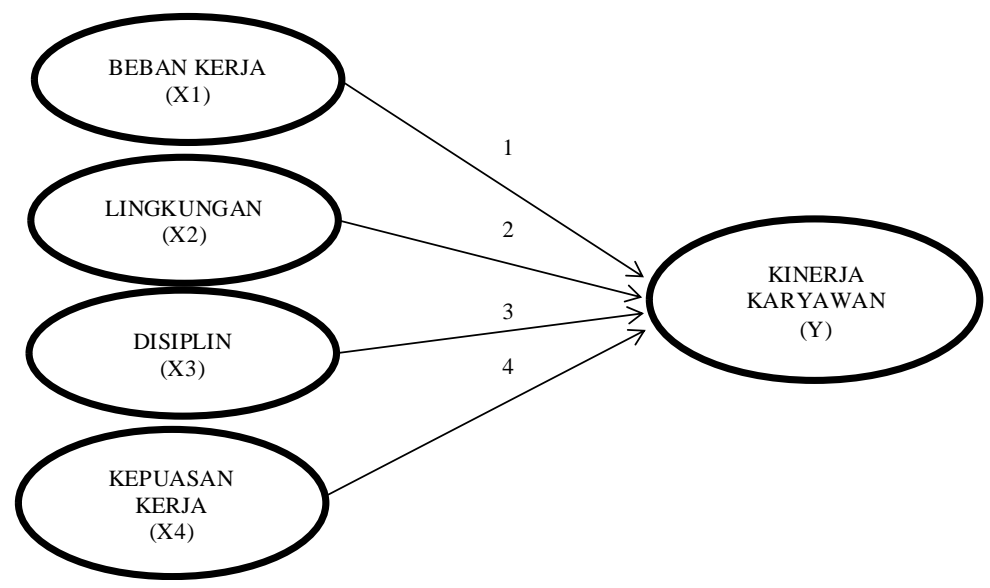

Gambar 1. Hipotesis

\section{METODE PENELITIAN}

Penelitian ini digolongkan dalam jenis penelitian deskriptif kuantitatif Penelitian kuantitatif selaku metode ilmiah karena sesuai kaidah - kaidah objektif yakni konkrit ataupun empiris, obyektif, terukur, logis serta sistematis (Sugiyono, 2019: 7), metode penelitian kuantitatif ialah metode penelitian yang berlandaskan pada filosofi positivisme, guna meneliti populasi serta sampel khusus, pengambilan sampel dilaksanakan dengan acak, instrumen penelitian berguna selaku pengumpulan data, sifat dari analisis data ini yakni kuantitatif/statistik dimana berfungsi guna malaksanakan pengujian hipotesis yang telah ditentukan. Populasi merupakan keseluruhan dari subjek penelitian (Arikunto, 2019: 173). Populasi untuk penelitian ini yakni semua karyawan PT Intan Pariwara pada divisi Finance \& Accounting total 109 orang. Metode sampling 
Jenuh/Sensus dijadikan sebagai

teknik pengambilan sampel ini.

HASIL PENELITIAN

A. Uji Regresi Linier Berganda

Tabel 1. Hasil Regresi Linier Berganda

\begin{tabular}{cccc}
\hline No & Variabel & Unstandardized B & Keterangan \\
\hline 1 & (Constant) & 1,596 & Positif \\
2 & Beban Kerja & 0,341 & Positif \\
3 & Lingkungan & 0,476 & Positif \\
4 & Disiplin & 0,212 & Positif \\
5 & Kepuasan Kerja & 0,186 & Positif \\
\hline
\end{tabular}

Persamaan regresi yang

dirumuskan sesuai tabel yakni:

$\mathrm{Y}=1,596+0,341 \mathrm{X}_{1}+0,476 \mathrm{X}_{2}$

$$
+0,212 X_{3}+0,186 X_{4}
$$

Penjelasan dari persamaan tersebut yakni:

a. Konstanta $(\mathrm{a})=1,596$

Bahwasanya jikalau nilai

konstanta (a) $=1,596$ lalu variabel beban kerja, lingkungan, disiplin, dan kepuasan kerja dihitung konstan ataupun samadengan nol, sehingga variabel kinerja karyawan sebesar 1,596 serta didapatkan hasil yang positif.

b. Koefisien Beban Kerja $\left(b_{1}\right)=$ 0,341

Bahwasanya jikalau nilai koefisiensi variabel beban kerja terjadi peningkatan, lalu variabel lingkungan, disiplin serta kepuasan kerja diibaratkan nilai dari model regresi yaitu tetap, sehingga nilai kinerja karyawan mengalami kenaikan sebanyak $0,341 \quad$ serta menghasilkan nilai yang positif.

c. Koefisien Lingkungan $\left(b_{2}\right)=$ 0,476

Bahwasanya jikalau nilai koefisiensi variabel lingkungan meningkat, lalu variabel beban kerja, disiplin dan kepuasan kerja diibaratkan nilai dari model regresi adalah tetap, sehingga nilai kinerja karyawan mengalami kenaikan sebanyak 0,476 dan menghasilkan nilai yang positif.

d. Koefisien Disiplin $\left(b_{3}\right)=0,212$

Bahwasanya jikalau nilai koefisiensi variabel disiplin meningkat, sebaliknya variabel beban kerja, lingkungan dan kepuasan kerja diibaratan nilai dari model regresi ialah tetap, sehingga nilai kinerja karyawan mengalami kenaikan 0,212 hal tersebut menghasilkan nilai yang positif.

e. Koefisien Kepuasan Kerja ( $\left.b_{4}\right)$ $=0,186$

Bahwasanya jikalau nilai koefisiensi variabel kepuasan kerja meningkat, sebaliknya variabel beban kerja, lingkungan, dan disiplin diibaratkan nilai dari model regresi yaitu tetap, sehingga nilai kinerja karyawan meningkat $\quad 0,186 \quad$ serta menghasilkan nilai yang positif. 


\section{B. Uji Hipotesis}

Uji F

Tabel 2. Uji F

\begin{tabular}{cccccc}
\hline Model & $\mathrm{F}_{\text {hitung }}$ & $\mathrm{F}_{\text {tabel }}$ & Sig. & Standar & Keterangan \\
\hline Regression & 20,922 & 2,46 & 0,000 & 0,05 & Model Layak
\end{tabular}

Dari hasil uji kelayakan model diperoleh $F_{\text {hitung }}>F_{\text {tabel }}$ sebesar 20,922>2,46 dengan tingkat signifikan sebanyak 0,000 hal tersebut bahwasanya analisis ini signifikan dengan tingkat signifikasi kurang dari 0,05 sehingga $\mathrm{HO}$ ditolak serta $\mathrm{Ha}$ Uji t diterima. Atau ada pengaruh antara beban kerja, lingkungan, disiplin serta kepuasan kerja secara bersamaan serta signifikan terhadap Kinerja Karyawan PT. Intan Pariwara Klaten dan memenuhi untuk uji kelayakan model.

Tabel 3. Uji t

\begin{tabular}{cccccc}
\hline Hipotesis & $\mathrm{t}_{\text {hitung }}$ & $\mathrm{t}_{\text {tabel }}$ & Sig. & Standar & Keterangan \\
\hline H1 & 3,655 & $>1,983$ & 0,000 & 0,05 & Diterima \\
H2 & 5,928 & $>1,983$ & 0,000 & 0,05 & Diterima \\
H3 & 2,644 & $>1,983$ & 0,009 & 0,05 & Diterima \\
H4 & 2,712 & $>1,983$ & 0,008 & 0,05 & Diterima \\
\hline
\end{tabular}

Penjabaran sesuai hasil uji $\mathrm{t}$ tersebut pada hibotesis yakni:

a. Pengaruh Beban Kerja terhadap Kinerja Karyawan Variabel Beban Kerja didapatkan angka $t_{\text {hitung }}>t_{\text {tabel }}$ $(3,655>1,983) \quad$ serta signifikansi $0,000<0,05$ sehingga Ho ditolak serta $\mathrm{Ha}$ diperoleh. Bisa dikatakan bahwasanya terdapat akibat positif serta penting variabelbeban kerja terhadap Kinerja Karyawan PT. Intan Pariwara Klaten.

b. Pengaruh Lingkungan terhadap Kinerja Karyawan Variabel Lingkungan memiliki angka $t_{\text {hitung }}>t_{\text {tabel }}$ $(5,928>1,983) \quad$ serta signifikansi $0,000<0,05$ sehingga Ho ditolak dan $\mathrm{H}_{\mathrm{a}}$ diterima. Bisa dikatakan bahwasanya terdapat pengaruh yang positif serta signifikan variabel lingkungan terhadap Kinerja Karyawan PT. Intan Pariwara Klaten.

c. Pengaruh Disiplin terhadap Kinerja Karyawan

Variabel Disiplin

memiliki angka $t_{\text {hitung }}>t_{\text {tabel }}$ $(2,644>1,983) \quad$ serta signifikansi $0,009<0,05$ sehingga $\mathrm{Ho}$ ditolak dan $\mathrm{H}_{\mathrm{a}}$ diterima. Bisa dikatakan bahwasanya terdapat pengaruh positif serta signifikan variabel disiplin terhadap Kinerja Karyawan PT. Intan Pariwara Klaten. 
d. Pengaruh Kepuasan Kerja terhadap Kinerja Karyawan Variabel Kepuasan Kerja memiliki angka $t_{\text {hitung }}>t_{\text {tabel }}(2,712>1,983)$ serta signifikansi $\quad 0,008<0,05$ sehingga Ho ditolak dan $\mathrm{H}_{\mathrm{a}}$ diterima. Bisa dikatakan bahwasanya terdapat pengaruh yang positif serta signifikan variabel kepuasan kerja terhadap Kinerja Karyawan PT. Intan Pariwara Klaten.

Uji Koefisien Determinasi $\left(\mathbf{R}^{2)}\right.$

Tabel 4. Uji Koefisien Determinasi $\left(\mathrm{R}^{2)}\right.$

\begin{tabular}{ccrcc}
\hline Model & $\mathrm{R}$ & $\begin{array}{c}\mathrm{R} \\
\text { Square }\end{array}$ & $\begin{array}{c}\text { Adjusted R } \\
\text { Square }\end{array}$ & $\begin{array}{c}\text { Std. Error of the } \\
\text { Estimate }\end{array}$ \\
\hline 1 & 0,668 & 0,446 & 0,425 & 1,659 \\
\hline
\end{tabular}

Berdasarkan tabel diatas diketahui Adjusted $R$ Squaresebesar 0,425. Berdasarkan nilai Adjusted $R$ Square ini bisa dikatakan jika sebesar 42,5\% variabel Kinerja Karyawan diterangkan oleh variabel Beban Kerja, Lingkungan, Disiplin dan Kepuasan Kerja, sebaliknya sisanya sebesar 57,5\% ( $100 \%$ $42,5 \%$ ) variabel Kinerja Karyawan yang diterangkan oleh variabel lain yang tidak terdapat pada model atau tidak diamati dalam penelitian ini.

\section{Pembahasan}

1. Beban Kerja berpengaruh positif serta signifikansi terhadap Kinerja Karyawan, jikalau Variabel Beban Kerja dinaikkan, sehingga Kinerja Karyawan akan bertambah. Hal ini dapat diperoleh artian bahwasanya kinerja karyawan yang terjadi di PT. Intan Pariwara Klaten dapat diterangkan oleh variabel Beban Kerja.

Sesuai hasil SPPS 21 didapatkan $t_{\text {hitung }}>t_{\text {tabel }}(3,655>$ 1,983) serta signifikansi $0,000<$ 0,05. Bahwasanya Beban Kerja berpengaruh positif serta signifikansi terhadap kinerja karyawan. Hal ini dapat diperoleh artian bahwasanya makin tinggi Beban Kerja maka bisa menaikkan kinerja karyawan pada PT. Intan Pariwara Klaten.

2. Lingkungan berpengaruh positif terhadap Kinerja Karyawan, jikalau Variabel Lingkungan dinaikkan, sehingga Kinerja Karyawan makin bertambah. Hal ini dapat diperoleh artian bahwasanya kinerja karyawan yang terdapat di PT. Intan Pariwara Klaten dapat diterangkan oleh variabel Lingkungan. Berdasarkan hasil SPPS 21 didapatkan $t_{\text {hitung }}>\mathrm{t}_{\text {tabel }}(5,928>$ 1,983) serta signifikansi $0,000<$ 0,05 . Bahwasanya Lingkungan berpengaruh positif serta signifikansi terhadap kinerja karyawan. Hasil tersebut menunjukkan makin tinggi Lingkungan maka akan meningkatkan kinerja karyawan pada PT. Intan Pariwara Klaten.

3. Disiplin berpengaruh positif terhadap Kinerja Karyawan, jikalau Variabel Disiplin dinaikkan, sehingga Kinerja Karyawan makin bertambah. Hal ini dapat diperoleh artian 
bahwasanya kinerja karyawan yang terdapat di PT. Intan Pariwara Klaten dapat diterangkan oleh variabel Disiplin. Berdasarkan hasil SPPS 21 didapatkan $t_{\text {hitung }}>\mathrm{t}_{\text {tabel }}(2,644>$ 1,983) serta signifikansi $0,009<$ 0,05. Bahwasanya disiplin berpengaruh positif serta signifikansi terhadap kinerja karyawan. Hasil tersebut menunjukkan makin tinggi Disiplin maka akan meningkatkan kinerja karyawan pada PT. Intan Pariwara Klaten.

4. Kepuasan Kerja berpengaruh positif terhadap Kinerja Karyawan jikalau Variabel Kepuasan Kerja dinaikkan, sehingga Kinerja Karyawan makin bertambah. Hal ini dapat diperoleh artian bahwasanya kinerja karyawan yang terdapat di PT. Intan Pariwara Klaten Klaten dapat diterangkan oleh variabel Kepuasan Kerja. Berdasarkan hasil SPPS 21 didapatkan $t_{\text {hitung }}>$ $t_{\text {tabel }}(2,712>1,983)$ serta signifikansi $0,008<0,05$. Bahwasanya Kepuasan Kerja berpengaruh positif serta signifikansi terhadap kinerja karyawan. Hasil tersebut menunjukkan makin tinggi Kepuasan Kerja maka akan meningkatkan kinerja karyawan pada PT. Intan Pariwara Klaten.

5. Pengaruh beban kerja, lingkungan, disiplin serta kepuasan kerja terhadap kinerja karyawan PT. Intan Pariwara Klaten. Hasil perhitungan menggunakan SPSS versi 21 diperoleh nilai $\quad F_{\text {hitung }}=$ 20.922 lebih besar dari $\mathrm{F}_{\text {tabel }}=2,46$ dan nilai signifikansi 0,000 lebih kecil dari 0,05. Maka diperoleh hasil bahwasanya beban kerja, lingkungan, disiplin serta kepuasan kerja berpengaruh signifikan secara simultan terhadap kinerja karyawan PT. Intan Pariwara. Nilai koefisien determinan $\left(\mathrm{R}^{2}\right)$ yang dipakai guna menerangkan proporsi variasivariabel dependen yang diterangkan oleh variabel independen secara simultan menghasilkan angka 0,425. Hal tersebut menunjukkan bahwa variabel kinerja karyawan diterangkan oleh beban kerja, lingkungan, disiplin serta kepuasan kerja sebanyak 42,5\%. Sedangkan $57,5 \%$ diterangkan oleh variabel lain yang tidak diteliti dalam penelitian ini. Dari kedua hasil tersebut uji $\mathrm{F}$ dan koefisien determinan, maka bisa menjawab hipotesis pertama yaitu beban kerja, lingkungan, disiplin serta kepuasan kerja berpengaruh secara simultan terhadap kinerja karyawan PT. Intan Pariwara Klaten.

\section{KESIMPULAN DAN SARAN Kesimpulan}

Dari beberapa hasil uji hipotesis dan juga pembahasan rinci yang telah dilakukan dalam penelitian berikut dari 109 kuesioner yang telah dibagikan kepada karyawan PT. Intan Pariwara divisi Finance \& Accounting ditentukan bahwa variabel dari beban kerja, lingkungan, disiplin, serta kepuasan kerja berpengaruh yang positif serta signifikansi terhadap variabel kinerja karyawan pada PT. Intan Pariwara Klaten.

Koefisien determinasi dari penelitian yang telah dilakukan 
didapatkan hasil nilai Adjusted $R$ Square $\left(\mathrm{R}^{2}\right)$ sebanyak 0,425 ataupun $42,5 \%$. Bahwasanya determinasi ataupun sumbangan variabel beban kerja, lingkungan, disiplin serta kepuasan kerja terhadap kinerja karyawan PT. Intan Pariwara Klaten sebanyak $42,5 \%$. Sedangkan sisanya sumbangan variabel-variabel lain di luar penelitian, seperti motivasi kerja, pengaruh kompensasi kerja, dll sebesar $57,5 \%$.

\section{Saran}

1. Secara teoritis

Diharapkan penelitian berikutnya untuk meningkatkan penelitian ini dengan memakai variabel bebas lainnya selain beban kerja, lingkungan, disiplin, serta kepuasan kerja yang dapat mempengaruhi kinerja karyawan, mengingat adanya pengaruh sebesar $57,5 \%$ di luar variabel penelitian ini.

2. Secara praktis

a. Diharapkan PT. Intan Pariwara Klaten kedepannya tetap mempertahankan dan meningkatkan kualitas beban kerja, lingkungan, dan disiplin kerja yang ada. Tingginya kualitas beban kerja, lingkungan, dan disiplin kerja di PT. Intan Pariwara Klaten membuat kinerja karyawan akan makin naik serta menjadikan lebih baik dari sebelumnya.

b. Sebaiknya PT. Intan Pariwara Klaten juga meningkatkan kepuasan kerja agar karyawan merasa puas dan semakin semangat dalam bekerja. Adanya kepuasan kerja membuat karyawan lebih semangat dalam bekerja, merasa senang menjalani pekerjaannya dan pekerjaan yang ada akan semakin cepat dalam menyelesaikan pekerjaannya.

c. Bagi peneliti yang lain variabel kinerja juga bisa digunakan untuk penelitian diluar organisasi atau instansi pemerintah karena bisa digunakan untuk kemajuan suatu obyek yang teliti. Bisa juga digunakan di sektor perusahaan, pabrik, perbankan dan lain lain.

\section{DAFTAR PUSTAKA}

Arikunto. (2019). Prosedur Penelitian: Suatu Pendekatan Praktik. Jakarta: Rineka Cipta.

Danang, Sunyoto. (2015). Manajemen dan Pengembangan Sumber Daya Manusia. Yogyakarta: Center for Academic Publishing Service.

Ferawati, A. (2017). "Pengaruh Lingkungan Kerja dan Disiplin Kerja Terhadap Kinerja Karyawan". Agora. Vol.5, No.1. Hal. 1-3.

Hannani, A., Muzakkir., \& Ilyas, G. B. (2016). Pengaruh Beban Kerja, Kepuasan, Fasilitas Terhadap Kinerja Perawat Di Ruang Perawatan Mawar Lantai II Rumah Sakit Umum Wisata UTT Makasar. Jurnal Mirai Manajemen. Vol. 01, No. 02. Hal. 516-526.

Kasmir. (2016). Manajemen Sumber Daya Manusia (Teori dan Praktik). Depok: PT Rajagrafindo Persada.

Koesomowidjojo, Suci R. Mar'ih. 
(2017). Panduan Praktis Menyusun Analisis Beban Kerja (1st ed.). Jakarta: Penebar Suadaya.

Mangkunegara, A. P., \& Octored, T. R. (2015). Effect Of Work Discipline, Work Motivation and Job Satisfaction on Employee Organizational Commitment In The Company (Case Study In PT. Dada Indonesia). Universal Journal Of Management, Vol 3, Issue 8: Hal. 318-328.

Mufidah, Z. (2017). "Pengaruh Latar Belakang Pendidikan, Beban Kerja, dan Lingkungan Kerja Non Fisik Terhadap Kinerja Karyawan PT. Bank BNI Syariah Cabang Kediri”. Jurnal Ekonomi, Vol. 01 No. 05. Hal. 1-16.

Nurjaya, N., et al. (2021). Pengaruh Etos Kerja Dan Disiplin Kerja Terhadap Kinerja Pegawai Pada Dinas Kehutanan Dan Perkebunan Kota Bogor. JENIUS (Jurnal Ilmiah Manajemen Sumber Daya Manusia), 4(2), 172-184.

Sedarmayanti. (2011). Manajemen Sumber Daya Manusia. Reformasi Birokrasi dan Manajemen Pegawai Negeri Sipil, Cetakan Kelima. Bandung: PT Refika Aditama.

Sinambela, Poltak. Lijan. (2011). Kinerja Pegawai. Yogyakarta: Graha Ilmu.
Sinambela, Poltak. Lijan. (2018). Manajemen Sumber Daya Manusia. Jakarta: PT Bumi Aksara.

Sugiharjo, R., J, \& Aldata, F. (2018). "Pengaruh Beban Kerja dan Motivasi Kerja Terhadap Kinerja Karyawan BPJS Ketenagakerjaan Cabang Salemba". Jurnal Ilmiah Manajemen Bisnis, Vol. 4, No. 1. Hal. 128-137.

Sugiyono. (2019). Metodelogi Penelitian Kuantitatif, Kualitatif Dan R\&D. Bandung: Alfabeta.

Sunarsi, D., Wijoyo, H., Prasada, D., \& Andi, D. (2020). "Pengaruh Lingkungan Kerja Terhadap Kinerja Karyawan Pada PT. Mentari Persada di Jakarta". Jurnal Ekonomi dan Bisnis, Vol. 5. No. 1. Hal. 117-123.

Sutrisno, Edy. (2014). Manajemen Sumber Daya Manusia. Cetak Ke Enam. Jakarta: Pranada Media Group.

Veithzal, Rivai. (2013). Manajemen Sumber Daya Manusia Untuk Perusahaan Dari Teori Ke Praktek. Bandung: Rajagrafindo Persada.

Zahara, Rizki Novriyanti., \& Hidayat, Hajan. (2017). "Pengaruh Kepuasan dan Disiplin Kerja Terhadap Kinerja Karyawan Bank di Kota Batam", Jurnal Manajemen Bisnis, Vol. 1, No, 2. Hal. 1-7. 